\title{
Prevalence and co-infection of mosquito- and tick-borne pathogens in domestic dogs suspected for canine babesiosis in Lithuania
}

\author{
Jana Radzijevskaja ${ }^{{ }^{*}}$, \\ Dovilè Tamoliūnaité ${ }^{1}$, \\ Vytautas Sabūnas², \\ Asta Aleksandravičiené $\dot{1}^{1}$ \\ Algimantas Paulauskas ${ }^{1}$ \\ ${ }^{1}$ Vytautas Magnus University, \\ K. Donelaičio St. 58, \\ Kaunas 44248, Lithuania \\ ${ }^{2}$ Linas Veterinary Clinic, \\ Debreceno St. 5 , \\ Klaipeda 94175, Lithuania
}

During the past decade, vector-borne diseases (VBDs) have been continuously spreading in Europe, including Lithuania. VBDs are caused by bacteria, parasites, or viruses transmitted by the bite of hematophagous arthropods (mainly ticks and mosquitoes). Canine vector-borne diseases (CVBDs) are a growing global threat. Since the majority of these diseases have a zoonotic potential, their management requires a multidisciplinary approach. Global warming and simplified rules for travelling with animal companions provide ideal conditions for the circulation and spreading of vector-borne pathogens in non-endemic geographical regions. Information on CVBD agents at the local and regional levels allows veterinarians to better recognize the pathogens that can affect dogs, thus facilitating diagnosis and treatment. The aim of the present study was to investigate the prevalence and co-infection of mosquito- and tick-borne pathogens in domestic dogs using molecular DNA analysis methods. Blood samples were collected from dogs presented at different veterinary clinics in six regions of Lithuania. A total of 100 blood samples from dogs suspected for canine babesiosis were screened for the presence of tick-borne pathogens Anaplasma phagocytophilum, Borrelia spp., Babesia canis and mosquito-borne pathogens Dirofilaria spp. Results of real-time PCR analysis demonstrated the presence of D. repens in $23.0 \%$, A. phagocytophilum in $35.0 \%$, Babesia spp. in $81.0 \%$, and Borrelia spp. in $19.0 \%$ of examined dogs. Double, triple, or even quadruple co-infections were detected. The present study is the first investigation of multiple vector-borne pathogens in dogs from Lithuania using molecular detection methods. Our findings demonstrate a high infection rate of vector-borne pathogens in dogs and suggest that co-infections with anaplasmosis, borreliosis, babesiosis, and dirofilariosis in dogs are expected in Lithuania.

Keywords: domestic dogs, Babesia canis, Dirofilaria repens, Anaplasma phagocytophilum, Borrelia burgdorferi sensu lato, Lithuania

\footnotetext{
*Corresponding author. Email: jana.radzijevskaja@vdu.lt
} 


\section{INTRODUCTION}

In humans and animals, vector-borne diseases (VBDs) are caused by bacteria, parasites or viruses transmitted by the bite of hematophagous arthropods (mainly ticks and mosquitoes) (Beugnet, Marié, 2009). Canine vector-borne diseases (CVBDs) are a growing global threat. The majority of these diseases have a zoonotic potential therefore their management requires a multidisciplinary approach (Parola et al., 2005). Climatic changes, together with an increase in the movement of domestic dogs across Europe, have caused an increase in the geographical range of several vector-borne parasites (Cringoli et al., 2001).

Dirofilariosis is an emerging vector-borne parasitic zoonotic infection caused by nematodes of the genus Dirofilaria and transmitted by mosquitoes (Simón et al., 2012). The majority of cases in humans and animals are caused by two Dirofilaria species, Dirofilaria repens and Dirofilaria immitis, (McCall et al., 2008). The definitive mammalian hosts for Dirofilaria pathogens are primarily domestic dogs and wild canids. Adult nematodes of $D$. repens most often are found in subcutaneous tissues, whereas $D$. immitis is the causal agent of canine and feline cardiopulmonary dirofilariosis (Genchi et al., 2005). The microfilariae are found in peripheral blood and waiting to be picked up by a mosquito. Most of $D$. repens-infected dogs are asymptomatic. In some dogs, the infection induces localized dermatitis, skin nodules, pruritus, thinning, and asthenia (Genchi et al., 2009). In Lithuania, the first case of canine subcutaneous dirofilariosis was recorded in 2010. A recent study conducted in Lithuania reported $2.7 \%$ overall prevalence of $D$. repens infection in pet and shelter dogs (Sabūnas et al., 2019). Accurate identification of $D$. repens species in dogs is clinically important because of the zoonotic concerns and therapeutic implications in veterinary clinics.

Tick-borne infection canine babesiosis caused by Babesia canis is an emerging infectious disease in Europe (Irwin, 2009). Although previously uncommon, canine babesiosis has become quite frequent in Lithuania during the past decade. Expansion of B. canis in Lithuania, as in other European countries, is directly related to the expanding range of the main vector - Dermacentor reticulatus tick (Paulauskas et al., 2015). Tick-borne infection caused by bacterium Anaplasma phagcytophilum is a well-known disease in Europe and the USA. Due to the spread of Ixodid ticks, the geographical distribution of $A$. phagocytophilum is expanding to the regions of Northern Europe (Carrade et al., 2009). A. phagocytophilum has been detected in blood samples from a wide range of wild and domestic animals. Most dogs naturally infected with $A$. phagocytophilum probably remain healthy, as indicated by the high number of healthy seropositive dogs relative to dogs with the clinical disease (Kohn et al., 2011).

Lyme borreliosis (LB) is a zoonotic disease caused by the spirochete Borrelia burgdorferi sensu lato (Littman et al., 2006). The disease is transmitted primarily by ticks feeding on mammals and birds, with the most common vectors in Europe being Ixodes ricinus and Ixodes persulcatus. Much less is known about LB in animals than about the disease in humans (Goossens et al., 2001). The most common symptom of LB in dogs is migratory arthritis; carditis, glomerulonephritis, and neuritis are less common. In Europe, antibodies to B. burgdorferi s.l. and clinical symptoms of LB in dogs have been reported in several studies (reviewed by Goossens et al., 2001). If Lyme borreliosis is diagnosed early and treated correctly, the outcomes are generally considered to be excellent and dogs recover quickly. PCR tests for B. burgdorferi s.l. from blood can detect active infection sooner than serologic tests.

Infection with $A$. phagocytophilum and Borrelia spp. in dogs is mostly asymptomatic or characterized by nonspecific clinical signs, therefore it is especially important to use appropriate methods for early diagnosis of pathogens.

Co-infections with different VBDs are common, because some species are transmitted in the same arthropod vector (Víchová et al., 2014). Most vector-borne diseases have the 
special feature of causing similar clinical signs and abnormal laboratory findings in dogs. Coinfected cases are complicated for practitioners and may cause failures in diagnosis, treatment, and prognosis (Cardoso et al., 2010; Gaunt et al., 2010; De Tommasi et al., 2013).

The aim of the present study was to investigate the prevalence and co-infection of mosquito- and tick-borne pathogens in domestic dogs using molecular DNA analysis methods.

\section{MATERIALS AND METHODS}

Blood samples from dogs of different breeds and age groups suspected for canine babesiosis were collected by veterinary practitioners from seven Lithuanian veterinary clinics (in Marijampolè, Vilnius, Klaipèda, Panevèžys, Kedainiai, and two veterinary clinics in Kaunas) from 2016 to 2019 (Table 1).

A total of 100 blood samples were analyzed for the presence of different vector-borne pathogens using molecular detection methods (Table 1). DNA was isolated from $200-\mu \mathrm{l}$ aliquots of EDTA blood using the GeneJet Whole Blood Genomic DNA purification kit (Thermo Fisher Scientific, Lithuania) as per manufacturer's instructions.

Partial internal transcribed spacer region 2 (ITS2) of the ribosomal RNA and cytochrome c oxidase subunit I ( $\operatorname{cox} 1)$ gene were used as targets in PCR for identification of Dirofilaria microfilariae species (Rishniw et al., 2006). PCR results were evaluated by agarose gel electrophoresis.

The samples were screened for the presence of tick-borne pathogens A. phagocytophilum, Babesia spp. and Borrelia spp. using multiplex real time-PCR assay designed by Maksim Bratchikov (Sakalauskas et al., 2019) to amplify a $98 \mathrm{bp}$ fragment of $m s p 2$ gene from A. phagocytophilum, a 214 bp fragment of $18 S$ rRNR gene from Babesia spp., and a 77 bp fragment of $23 S$ rRNR gene from Borrelia spp. Multiplex TaqMan real time-PCR was performed in a total volume of $15 \mu \mathrm{l}$ consisting of $100 \mathrm{ng}$ of extracted DNA, (1x) SensiMix ${ }^{\text {tix }}$ II Probe No-ROX (Bioline), $1 \mu \mathrm{M}$ of each primer, and $0.5 \mu \mathrm{M}$ of each probe. The following PCR conditions were used: an initial denaturation at $95^{\circ} \mathrm{C}$ for $10 \mathrm{~min}$, followed by 45 cycles of denaturation at $95^{\circ} \mathrm{C}$ for $20 \mathrm{~s}$, and annealing-extension at $60^{\circ} \mathrm{C}$ for $1 \mathrm{~min}$. For all real-time PCR reactions, samples were considered positive if they had a cycle threshold (CT) value $<40$. Positive samples from real-time PCR were used in further amplifications in order to obtain PCR products for sequence analysis. Partial msp4 gene of A. phagocytophilum and $16 \mathrm{~S}$ ( $\mathrm{rrs}$ )-23S (rrlA) intergenic spacer (ITS region) of Borrelia spp. were amplified by nested PCRs. The amplification of $B$. canis DNA through conventional PCR was performed using primers BAB GF2 and BAB GR2, which amplify a 559 bp region of the $18 S r R N A$ gene of $B$. canis (Adaszek et al., 2009).

Representative positive PCR products were extracted from the agarose gel and purified using the GeneJet PCR purification kit (Thermo Fisher Scientific, Lithuania) as per manufacturer's instructions and further subjected to sequence analysis. The obtained sequences were analyzed using the Mega software package, version $\mathrm{X}$, and compared with the sequence data available from GenBank using the BLAST program. Phylogenetic trees were constructed on the basis of the sequence distance method using the Neighbor joining and Maximum Likelihood algorithms.

\section{RESULTS AND DISCUSSION}

\section{Detection of $D$. repens}

The identification of $D$. repens was performed on the basis of $484 \mathrm{bp}$ fragments of ITS-2 region. Blood samples positive for microfilaria were then verified with a $D$. repens-specific primer set based on partial (209 bp) amplification of $\operatorname{cox} 1$ gene, as described by Rishniw et al. (2006). Based on both PCR assays, D. repens was identified in $23.0 \%$ of examined dogs (Figs. 1, 2; Table 1). The sequence analysis of the partial coxl gene showed that two D. repens sequences were $99-100 \%$ identical to the corresponding $D$. repens sequences deposited in GenBank. Two cox 1 gene sequences 


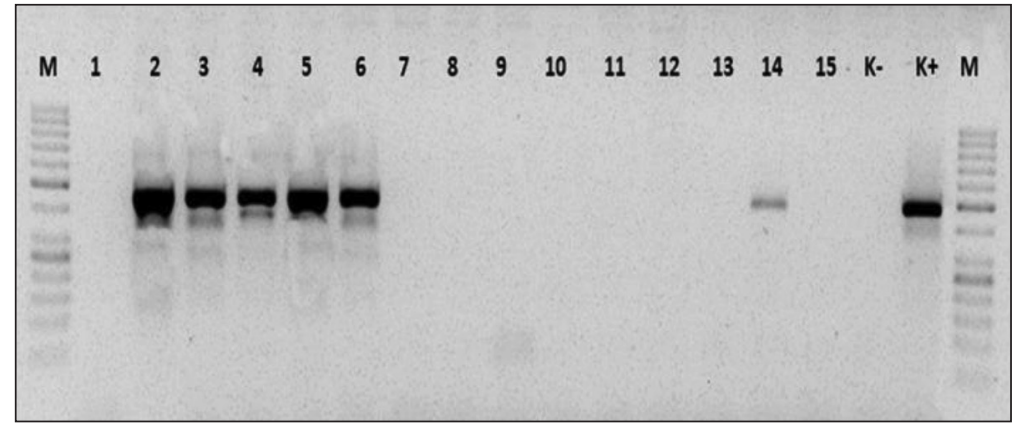

Fig. 1. PCR amplification of partial ITS-2 region of filarial species visualized by electrophoresis in a $1.5 \%$ agarose gel: $2-6,14$ tracks $D$. repens-positive samples; M - molecular weight marker 50 bp; $\mathrm{K}$ - negative control; $\mathrm{K}+$ positive control

Fig. 2. PCR amplification of partial coxl gene of $D$. repens visualized by electrophoresis in a $1.5 \%$ agarose gel. 1-7 tracks D. repenspositive samples; $\mathrm{M}-$ molecular weight marker $50 \mathrm{bp}$; $\mathrm{K}$ - negative control; $\mathrm{K}+$ positive control

Table 1. Vector-borne pathogens detected in dogs in different veterinary clinics in Lithuania

\begin{tabular}{c|c|ccccc}
\hline \multirow{2}{*}{ Location } & \multirow{2}{*}{$\begin{array}{c}\text { trepens } \\
\mathbf{n} / \mathbf{N}\end{array}$} & \multicolumn{3}{|c|}{ Real time PCR } & Nested PCR \\
\cline { 3 - 6 } & A. phagocytophilum & Borrelia spp. & Babesia spp. & A. phagocytophilum \\
\hline Kèdainiai & $1 / 1$ & $1 / 1$ & $0 / 1$ & $1 / 1$ & $0 / 1$ \\
\hline Vilnius & $0 / 5$ & $5 / 5$ & $5 / 5$ & $5 / 5$ & $2 / 5$ \\
\hline Panevė̌̌ys & $1 / 8$ & $4 / 8$ & $3 / 8$ & $8 / 8$ & $1 / 4$ \\
\hline Marijampole & $1 / 4$ & $3 / 4$ & $2 / 4$ & $4 / 4$ & $0 / 3$ \\
\hline Klaipėda & $0 / 5$ & $2 / 5$ & $1 / 5$ & $5 / 5$ & $0 / 2$ \\
\hline Kaunas & $20 / 77$ & $20 / 77$ & $8 / 77$ & $58 / 77$ & $2 / 20$ \\
\hline Total & $23 / 100$ & $35 / 100$ & $19 / 100$ & $81 / 100$ & $5 / 35$ \\
\hline
\end{tabular}

(17 Kr, 1Mar; Table 2) were 100\% identical to corresponding sequences of $D$. repens previously detected in dogs from Lithuania (Sabūnas et al., 2019), while three other cox1 sequences of $D$. repens were distinguished from the sequences available in GenBank based on one nucleotide substitutions (T/C) at the positions $146 \mathrm{nt}$ in the analysed sequence (Table 2). Three cox 1 gene sequences of D. repens were deposited in GenBank under accession numbers MT345562 (1Ked), MT345563 (10Sn), MT345564 (41Sn). Phylogenetic rela- tionship among cox 1 gene sequences of filarioid nematodes are presented in Fig. 3. Results of this study demonstrated that at least two cox 1 gene haplotypes of $D$. repens circulate in Lithuania.

Detection of A. phagocytophilum, Borrelia spp. and Babesia spp.

Results of real-time PCR analysis demonstrated the presence of DNA of Babesia spp. in $81.0 \%$ (81/100), A. phagocytophilum in $35.0 \%$ (35/100), and Borrelia spp. in 19.0\% (19/100) of 
Table 2. Variable nucleotides detected in coxl gene sequence ( $209 \mathrm{bp}$ ) of $D$. repens isolates from Lithuania and other countries

\begin{tabular}{c|c|c}
\hline Samples & \multicolumn{2}{c}{ Nucleotide positions } \\
\hline & 146 & 155 \\
\hline 10Sn Dirofilaria repens Lithuania & $\mathrm{C}$ & $\mathrm{G}$ \\
\hline 41Sn Dirofilaria repens Lithuania & $\cdot$ & $\cdot$ \\
\hline 1Ked Dirofilaria repens Lithuania & $\cdot$ & $\cdot$ \\
\hline 17Kr Dirofilaria repens Lithuania & $\cdot$ & $\cdot$ \\
\hline 1Mar Dirofilaria repens Lithuania & $\mathrm{T}$ & $\cdot$ \\
\hline MH469227 Dirofilaria repens Lithuania & $\mathrm{T}$ & $\cdot$ \\
\hline MG787424 Dirofilaria repens Slovakia & $\mathrm{T}$ & $\cdot$ \\
\hline AJ271614 Dirofilaria repens Italy & $\mathrm{T}$ & $\cdot$ \\
\hline MH469229 Dirofilaria repens Lithuania & $\mathrm{T}$ & $\cdot$ \\
\hline KC142193 Dirofilaria repens Slovakia & $\mathrm{T}$ & $\cdot$ \\
\hline MF695085 Dirofilaria repens Austria & $\mathrm{T}$ & $\mathrm{A}$ \\
\hline
\end{tabular}

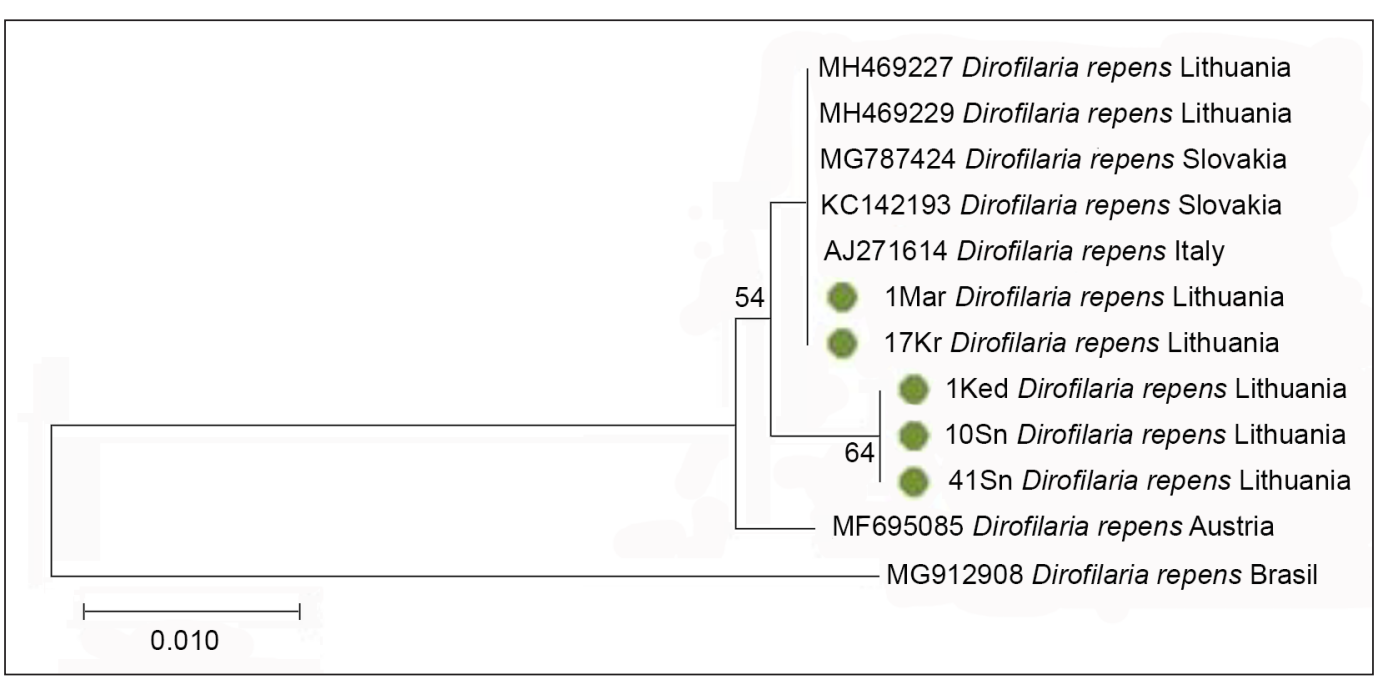

Fig. 3. Phylogenetic tree of the cox 1 gene sequences of $D$. repens created using the NeighborJoining method and bootstrap analysis of 1000 replicates. Sequences with accession numbers were taken from GenBank for comparison. Samples sequenced in the present study are marked

examined dogs (Table 1). For positive A. phagocytophilum samples, CT values varied from 14 to 39 cycles. For positive Babesia samples, CT values varied from 18 to 36 cycles. For Borrelia spp. positive samples, CT values ranged between 33 and 38 cycles, which demonstrated low bacteremia in the analysed samples.

In all positive samples, $B$. canis was identified based on amplifications of $559 \mathrm{bp}$ fragments of
$18 \mathrm{~S}$ rRNA in species-specific PCR. A. phagocytophilum msp4 gene was successfully amplified in five out of 35 (14.3\%) samples positive for this pathogen by real-time PCR. Sequence analysis of the partial (381 bp) msp4 gene of A. phagocytophilum showed that all three sequences were $100 \%$ identical to each other and to the corresponding sequences deposited in the GenBank database (Fig. 4). 


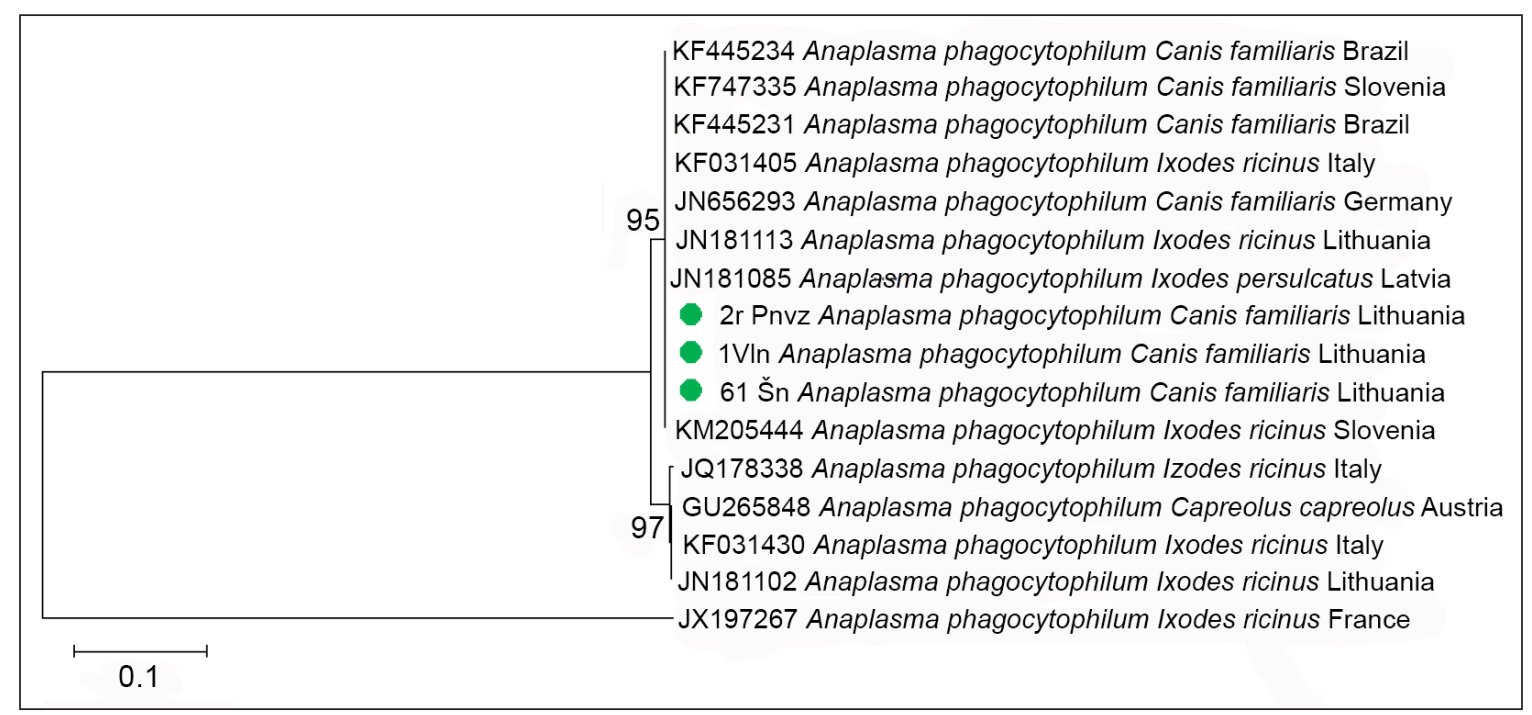

Fig. 4. Phylogenetic tree of the msp4 gene sequences of $A$. phagocytophilum created using the Maximum Likelihood method and bootstrap analysis of 1000 replicates. Sequences with accession numbers were taken from GenBank for comparison. Samples sequenced in the present study are marked

Amplification of partial ITS region (varied from 450 to 1500 bp depending on Borrelia species) of Borrelia spp. by nested PCR were not successful, most likely because of a low load of bacteria in examined samples. Realtime PCR method was more effective in identifying of Borrelia DNA.

Vector-borne infections are increasingly important to the health of people and other animals worldwide. Tick-borne diseases are of great medical importance worldwide and affect dogs' health through the transmission of pathogens by blood sucking Ixodidae ticks. The geographic distribution of infected ticks has expanded because of bird migration as well as environmental and climatic changes. Climate change has already affected a wide range of vector-borne diseases in Europe. Ticks and mosquitoes, the diseases they transmit have a geographical range restricted by host movement and climatic factors. The increased mobility of domestic dogs has resulted in rapid extension of the geographical ranges for their ectoparasites and carried pathogens (Gray et al., 2008). All these factors may increase the risk of babesiosis, dirofilariosis, anaplasmosis, and Lyme borreliosis for dogs in Lithuania.

\section{Co-infections}

A. phagocytophylum spp. and Borrelia spp. coinfection was detected in nine samples (9\%). Borrelia spp. and Babesia spp. co-infection was found in three samples (3\%). In six samples (6\%), A. phagocytophylum and B. canis co-infection was detected. Triple infections with A. phagocytophilum, B. canis, and Borrelia spp. were detected in seven samples. The high number of co-infections is due to the fact that ticks may be co-infected with several pathogens, with a subsequent high likelihood of co-transmission to animals. Out of 23 D. repens-infected dogs, 14 (60.9\%) were co-infected with different tick-borne pathogens: four $(28.6 \%)$ samples were co-infected with $B$. canis; three (21.4\%) samples were coinfected with $A$. phagocytophilum and Borrelia spp.; two (14.2\%) samples were co-infected with A. phagocytophilum and B. canis; other two $(14.2 \%)$ samples were co-infected with A. phagocytophilum; one sample (7.1\%) was infected with Borrelia spp. Quadruple co-infection with $D$. repens, A. phagocytophilum, Borrelia spp., and B. canis was detected in two samples (14.2\%). The highest co-infection rate (28.6\%) was detected between $D$. repens and B. canis pathogens. In warm climate countries, 
where a large spectrum of different vectors is found, co-infections in dogs with Ehrlichia, Anaplasma, Babesia, Borrelia, Bartonella, Rickettsia, and Dirofilaria are detected (Beall et al., 2008; Sainz et al., 2015; Capelli et al., 2018). Findings of the present study suggest that co-infections with anaplasmosis, babesiosis, and dirofilariosis in dogs are expected in Lithuania. Co-infection cases are complicated for practitioners and may cause failures in diagnosis, treatment, and prognosis (Cardoso et al., 2010; De Tommasi et al., 2013). The results of this study may be useful in developing molecular diagnostic kits for infectious diseases using a real-time multiplex PCR method, which can detect multiple pathogens simultaneously (Courtney et al., 2004; Hojgaard et al., 2014). Diagnostic kits for different vector-borne diseases could be based on epidemiological data of different countries (De Tommasi et al., 2013).

\section{CONCLUSIONS}

The present study is the first investigation of multiple vector-borne pathogens in dogs from six different locations in Lithuania using molecular detection methods. Our study demonstrated a high prevalence of mosquito- and tick-borne infections in Lithuanian dogs and suggested that co-infections with anaplasmosis, borreliosis, babesiosis, and dirofilariosis are expected. Double, triple, or even quadruple coinfections were detected in the present study. Annual testing for mosquito- and tick-borne infections using modern molecular diagnostic methods is recommended for veterinarians.

\section{ACKNOWLEDGEMENTS}

This research is funded by the measure "Development of Competences of Scientists, Other Researchers and Students through Practical Research Activities" of the European Social Fund No. 09.3.3-LMT-K-712-10-0287.

Received 28 April 2020 Accepted 14 May 2020

\section{References}

1. Adaszek $€$, Winiarczyk S, Skrzypczak M. The clinical course of babesiosis in 76 dogs infected with protozoan parasites Babesia canis canis. Pol J Vet Sci. 2009; 12(1): 81-7.

2. Beall MJ, Chandrashekar R, Eberts MD, Cyr KE, Diniz PP, Mainville C, Hegarty BC, Crawford JM, Breitschwerdt EB. Serological and molecular prevalence of Borrelia burgdorferi, Anaplasma phagocytophilum, and Ehrlichia species in dogs from Minnesota. Vector Borne Zoonotic Dis. 2008; 8(4): 455-64.

3. Capelli G, Genchi C, Baneth G, Bourdeau P, Brianti E, Cardoso L, Danesi P, Fuehrer HP, Giannelli A, Ionică AM, Maia C, Modrý D, Montarsi F, Krücken J, Papadopoulos E, Petrić D, Pfeffer M, Savić S, Otranto D, Poppert S, Silaghi C. Recent advances on Dirofilaria repens in dogs and humans in Europe. Parasit Vectors. 2008; 11(1): 663.

4. Cardoso L, Yisaschar-Mekuzas Y, Rodrigues FT, Costa Á, MacHado J, Diz-Lopes D, Baneth G. Canine babesiosis in northern Portugal and molecular characterization of vector-borne co-infections. Parasit Vectors. 2010; 3(1): 27.

5. Carrade DD, Foley JE, Borjesso DL, Sykes JE. Canine Granulocytic Anaplasmosis: A Review. J Vet Intern Med. 2009; 23(6): 1129-41.

6. Cringoli G, Rinaldi L, Veneziano V, Capelli G. A prevalence survey and risk analysis of filariosis in dogs from the Mt. Vesuvius area of southern Italy. Vet Parasitol. 2001; 102(3): 243-52.

7. De Tommasi AS, Otranto D, Dantas-Torres F, Capelli G, Breitschwerdt EB, De Caprariis D. Are vector-borne pathogen co-infections complicating the clinical presentation in dogs? Parasit Vectors. 2013; 6: 97.

8. Gaunt S, Beall M, Stillman B, Lorentzen L, Diniz P, Chandrashekar R, Breitschwerdt E. Experimental infection and co-infection of dogs with Anaplasma platys and Ehrlichia canis: hematologic, serologic and molecular findings. Parasit Vectors. 2010; 3(1): 33. 
9. Genchi C, Rinaldi L, Cascon C, Mortarino M, Cringoli $\mathrm{G}$. Is heartworm disease really spreading in Europe? Vet Parasitol. 2005; 133(2-3): $137-48$.

10. Genchi C, Rinaldi L, Mortarino M, Genchi M, Cringoli G. Climate and Dirofilaria infection in Europe. Vet Parasitol. 2009; 163(4): 286-92.

11. Goossens HAT, Van Den bogaard AE, Nohlmans MKE. Dogs as sentinels for human Lyme Borreliosis in the Netherlands. J Clin Microbiol. 2001; 39(3): 844-8.

12. Gray JS, Dautel H, Estrada-Pena A, Kahl O, Lindgren E. Effects of climate change on ticks and tick-borne diseases in Europe. Interdiscip Perspect Infect Dis. 2009; 2009: 593232.

13. Hojgaard A, Lukacik G, Piesman J. Detection of Borrelia burgdorferi, Anaplasma phagocytophilum and Babesia microti, with two different multiplex PCR assays. Ticks Tick Borne Dis. 2014; 5(3): 349-51.

14. Kohn B, Silaghi C, Galke D, Arndt G, Pfister K. Infections with Anaplasma phagocytophilum in dogs in Germany. Res Vet Sci. 2011; 91(1): 71-6.

15. Littman MP, Goldstein RE, Labato MA, Lappin MR, Moore GE. ACVIM small animal consensus statement on Lyme disease in dogs: diagnosis, treatment, and prevention. J Vet Int Med. 2006; 20(2): 422-34.

16. McCall JW, Genchi C, Kramer L, Guerrero J, Dzimianski MT, Supakorndej P, Mansour AM, McCall SD, Supakorndej N, Grandi G, Carson B. Heartworm and Wolbachia: therapeutic implications. Vet Parasitol. 2008; 158(3): 204-14.

17. Parola P, Davoust B, Raoult D. Tick- and fleaborne rickettsial emerging zoonoses. Vet Res. 2005; 36(3): 469-92.
18. Paulauskas A, Radzijevskaja J, MardosaitèBusaitienè D, Aleksandravičienè A, Galdikas M, Krikštolaitis R. New localities of Dermacentor reticulatus ticks in the Baltic countries. Ticks Tick Borne Dis. 2015; 6(5): 630-5.

19. Rishniw M, Barr SC, Simpson KW, Frongillo MF, Franz M, Dominguez Alpiza JL. Discrimination between six species of canine microfilariae by a single polymerase chain reaction. Vet Parasitol. 2006; 135(3-4): 303-14.

20. Sabūnas V, Radzijevskaja J, Sakalauskas P, Petkevičius S, Karvelienė B, Žiliukienė J, Lipatova I, Paulauskas A. Dirofilaria repens in dogs and humans in Lithuania. Parasit Vectors. 2019; $12: 177$.

21. Sainz Á, Roura X, Miró G, Estrada-Peña A, Kohn B, Harrus S, Solano-Gallego L. Guideline for veterinary practitioners on canine ehrlichiosis and anaplasmosis in Europe. Parasit Vectors. 2015; 8: 75.

22. Sakalauskas P, Lipatova I, Radzijevskaja J, Paulauskas A. Pathogen screening in the red fox (Vulpes Vulpes) from Lithuania. Biologija. 2019; 65(4): 283-95.

23. Simón F, Siles-Lucas M, Morchón R, GonzálezMiguel J, Mellado I, Carretón E, MontoyaAlonso JA. Human and animal dirofilariasis: the emergence of a zoonotic mosaic. Clin Microbiol Rev. 2012; 25(3): 507-44.

24. Víchová B, Miterpáková M, Iglódyová A. Molecular detection of co-infections with Anaplasma phagocytophilum and/or Babesia canis canis in Dirofilaria-positive dogs from Slovakia. Vet Parasitol. 2014; 203(1-2): 167-72. 
Jana Radzijevskaja, Dovilè Tamoliūnaitè, Vytautas Sabūnas, Asta Aleksandravičienè, Algimantas Paulauskas

TARP NAMINIŲ ŠUNŲ BABEZIOZĖS UŽKRATĄ PLATINANČIU巳 UODŲ IR ERKIŲ PATOGENŲ BEI KOINFEKCIJŲ ATVEJŲ NUSTATYMAS LIETUVOJE

\section{Santrauka}

Pastaraisiais metais stebimas vis didesnis vektorių pernešamų ligų plitimas ị naujas geografines teritorijas Europoje, taip pat Lietuvoje. Vektorinès kilmès ligas sukelia bakterijos, parazitai ar virusai, kuriuos platina nariuotakojai kraujasiurbiai, dažniausiai - erkès ir uodai. Iš šunų vektorių pernešamų ligų labiausiai pasaulyje paplitusios erkių pernešamos ligos. Šių infekcijų kontrolè yra svarbi dèl patogenų zoonotinio potencialo. Skirtingi patogenai gali sukelti panašius ligos simptomus ir tai apsunkina ligų diagnozavimą. Vektorių plitimas ne endeminiuose geografiniuose regionuose siejamas su globaliu atšilimu, žemès ūkio veiklos pokyčiais bei žmonių kelionėmis su savo augintiniais i naujus regionus. Nuosekli informacija apie šunų vektoriu pernešamus sukèlëjus naujose vietovèse ar regionuose leidžia veterinarijos gydytojams tiksliau ir greičiau nustatyti patogenus, galinčius sukelti šunų ligas, palengvina ligų diagnozavimą ir gydymą. Šio tyrimo tikslas - molekuliniais DNR analizės metodais įvertinti naminių šunų užsikrètimą uodų ir erkių platinamais patogenais bei nustatyti koinfekcijų paplitimą. Šunų kraujo mėginiai buvo surinkti iš skirtingų Lietuvos veterinarijos klinikų šešiuose Lietuvos regionuose. Iš viso 100 šunų kraujo mėginių buvo patikrinta dèl erkių platinamų patogenų Anaplasma phagocytophilum, Borrelia spp., Babesia canis ir uodų pernešamų patogenų Dirofilaria spp. PGR analizè atskleidè, kad $23 \%$ šunų užsikrètè D. repens, $35 \%$ - A. phagocytophilum, $19 \%$ - Borrelia spp. ir $81 \%$ - Babesia spp. Šunų kraujo mėginiuose buvo aptiktos dvigubos, trigubos ar net keturgubos koinfekcijos. Šiame tyrime šiuolaikiniais molekuliniais tyrimo metodais pirmą kartą buvo ịvertintas naminių šunų užsikrètimas skirtingais vektorių pernešamais patogenais Lietuvoje bei nustatytos anaplazmozès, boreliozès, babeziozès ir dirofiliariozès sukèlèjų koinfekcijos.

Raktažodžiai: naminiai šunys, Babesia canis, Dirofilaria repens, Anaplasma phagocytophilum, Borrelia burgdorferi sensu lato, Lietuva 